\title{
POTENTIALLY USEFUL FLORA FROM THE TROPICAL RAINFOREST IN CENTRAL VERACRUZ, MEXICO: CONSIDERATIONS FOR THEIR CONSERVATION
}

\author{
Mireya Burgos-Hernández ${ }^{1,3}$, Gonzalo Castillo-Campos ${ }^{1}$ and María del Carmen \\ Vergara Tenorio ${ }^{2}$ \\ ${ }^{1}$ Instituto de Ecología A. C., Red de Biodiversidad y Sistemática, Carretera antigua \\ a Coatepec 351, El Haya, 91070 Xalapa, Veracruz, México. \\ ${ }^{2}$ Universidad Veracruzana, Centro de Investigaciones Tropicales, \\ Ex-Hacienda Lucas Martín, Privada de Araucarias s/n. Col. Periodistas, \\ 91019 Xalapa, Veracruz, México. \\ ${ }^{3}$ Author for correspondence: mireya_bh14@hotmail.com
}

\begin{abstract}
Tropical rainforests have been a valuable source of resources for human kind. However, this ecosystem is disappearing at an alarming rate, with only isolated fragments remaining in inaccessible zones and showing high probability of disappearing. The aim of this study was to identify tropical rainforest plant species with potential for human use in the central region of Veracruz, Mexico. A floristic inventory was compiled of rainforest fragments and secondary vegetation using the plotting method. The total area sampled was $5600 \mathrm{~m}^{2}$. Using the equation Clench model, the proportion of species inventoried was assessed. This was $85 \%(t q=0.85)$ for the rainforest and $90 \%(t q=0.9)$ for the secondary vegetation. A total of 338 species, 210 genera and 89 families were recorded. Using semistructured interviews with locals, a list of useful plants was drawn up and it was found that people recognized and used $47 \%$ of the species inventoried. Additionally, contingency tables and the Spearman correlation test were performed to determine the differences in knowledge and use of the vegetation among villages, as well as in the gender and age group of the respondents. Nevertheless, we found no significant differences $(P>0.05)$. The use value (UV) was calculated to analyze the use of flora. in order to assess the relationship between the UV and their ecological importance, the index of adjusted ecological importance value (AEIV) was obtained. We detected that the most used species are not necessarily those of greater ecological importance. The potentially useful flora was defined based on a literature research, in situ interviews, as well as on their visual and morphological characteristics.
\end{abstract}


According to the data, more than $50 \%$ of the inventoried species are potentially useful, mainly as ornamental and medicinal ones, and they provide new economic alternatives for the local people with a minimum impact on the rainforest.

Key words: conservation, ethnobotany, Mexico, potentially useful flora, rainforest, secondary vegetation.

\section{RESUMEN}

Las selvas tropicales perennifolias representan una fuente de recursos valiosos para la humanidad. Sin embargo, están desapareciendo a una velocidad alarmante, quedando solo fragmentos aislados localizados en zonas de difícil acceso y próximos a desaparecer. El objetivo de este estudio fue identificar las especies vegetales de la selva mediana perennifolia con características potenciales de uso en la región central del estado de Veracruz, México. Para ello se realizó un levantamiento florístico en fragmentos de selva y vegetación secundaria usando el método de muestreo por cuadros. El área total muestreada fue de $5600 \mathrm{~m}^{2}$. Mediante la ecuación del modelo de Clench, se evaluó la proporción de especies inventariadas, la cual fue de $80 \%(t q=0.8)$ para la selva y $90 \%(t q$ $=0.9)$ para la vegetación secundaria. Se registró un total de 338 especies, 210 géneros y 89 familias. A través de entrevistas semiestructuradas, se generó un listado de las plantas útiles y se encontró que la población conoce y usa $47 \%$ de estas especies. Se realizaron tablas de contingencia y un análisis de correlación de Spearman para determinar las diferencias entre el conocimiento y uso de la vegetación en las localidades, así como entre el género y el grupo de edad de los entrevistados. Sin embargo, no se hallaron diferencias significativas $(P>0.05)$. Para analizar el uso de la flora, se calculó el valor de uso (UV) y para evaluar la relación entre el valor de uso de las especies y su importancia ecológica, se obtuvo el índice ajustado de valor de importancia ecológica (AEIV). Con ello se detectó que las plantas más usadas no son necesariamente las de mayor importancia ecológica. La flora potencialmente útil fue definida con base en la revisión bibliográfica, las entrevistas y a sus características visuales y morfológicas. De acuerdo con los datos obtenidos, más de $50 \%$ de las especies inventariadas poseen este valor, principalmente como ornamentales y medicinales, y proporcionan nuevas alternativas económicas para los pobladores locales con un mínimo de destrucción de la selva tropical.

Palabras clave: conservación, etnobotánica, flora potencialmente útil, México, selva tropical, vegetación secundaria. 
Burgos-Hernández et al.: Potentially useful flora from the tropical rainforest, Veracruz, Mexico

\section{INTRODUCTION}

Tropical forests are the most diverse and productive forests on the planet (DíazGallegos et al., 2010). Nevertheless, they are quickly disappearing and many humid tropical regions are currently characterized by the presence of isolated and inaccessible rainforest fragments (Guevara and Lira-Noriega, 2004; Díaz-Gallegos et al., 2010). One of the immediate consequences of fragmentation is a decrease in habitat availability and the loss of biodiversity. Throughout history, ecosystem disturbances are tied to their use and available technology to harvest trees and attain land management (Bawa et al., 2004). The tropical forest provides many resources that people use and need. However, vegetation management has focused mainly on exploiting timber, with little concern for the different species and their benefits (Steffan-Dewenter et al., 2007). In rural areas of tropical regions, plant resource management includes taking advantage of the timber and non-forest timber products, crop production and livestock. Traditional or non-forest timber use of the forest consists of generally collecting plant material (e.g. seeds, flowers, fruits, leaves, roots, bark, latex, resins and other non-wood plant parts or products) for self-consumption (Ticktin, 2004; Shackleton and Shackleton, 2004; Mirjam et al., 2005). In some regions, these resources are commercialized and constitute the single source of income, so they represent an important part of the family budget at certain times of the year (Delvaux et al., 2009).

Particularly in Mexico, where only about $10 \%$ of its territory is humid, most of which was covered by tropical rainforest, it is estimated that there were originally about 22 million hectares of this ecosystem. Nowadays, this figure hardly reaches 800,000 ha. The remains of the current Mexican rainforest are scattered throughout the Lacandon region, the Chimalapas, in the states of Oaxaca and Veracruz (Anonymous, 2007). The last state mentioned has been known for maintaining the highest deforestation rates in the country. The tropical forest used to cover $65 \%$ of its surface, but now, this area has been reduced to only $3 \%$ of its territory, mainly due to anthropogenic activities (Anonymous, 2007).

In this context, the municipality of Atzalan, located in central Veracruz, is a good example of the situation described above. The area covered by rainforest has been dramatically reduced here in the last 12 years, with only small fragments remaining (Burgos-Hernández, 2007). These fragments are the only remaining areas of rainforest in this region of the State, therefore, their conservation is paramount.

For the Atzalan municipality, floristic studies and particularly studies of plant resources are scarce, highlighting the need for research to offer alternatives of use and management of plant resources and also to contribute to the knowledge, conservation 
and sustainable use of tropical rainforests. This is the first study that analyses the current and the potential use of plant species present in the fragments of rainforest and secondary vegetation in the central region of the State of Veracruz, Mexico. The aims of this study were: (1) to document people's knowledge, use and management of local plant resources, and (2) to identify plant species with biological and commercial potential features for their use, to add value to the rainforest fragments in order to counter the threat from destructive land uses such as logging and cattle ranching in Veracruz, Mexico.

\section{METHODS}

Study site

The only rainforest fragments recorded in the central region of the State of Veracruz are located in the municipality of Atzalan, at the "Sierra de Chiconquia-

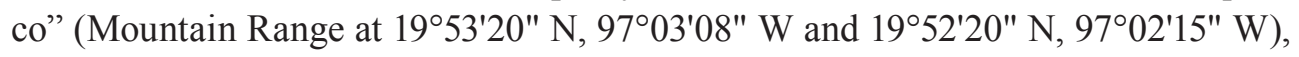
where the altitude ranges from 56 to $1799 \mathrm{~m}$ (Fig. 1). Atzalan has several types of vegetation ecosystems, among the most notable is the tropical rainforest, however, it has been highly perturbed by human activities and it heavily endangered.

This study was carried out in two rainforest fragments (35 ha and $15 \mathrm{ha}$ ) separated by the San Pedro River and surrounded by pastures, secondary vegetation and crops. The fragments are located between 600 and $800 \mathrm{~m}$ of altitude, among "San Pedro Altepepan", "La Vega del Río San Pedro" and "El Quimite” villages.

Description of the localities

La Vega del Río San Pedro is located at $19^{\circ} 52^{\prime} 31^{\prime \prime} \mathrm{N}$ and $97^{\circ} 03^{\prime} 20^{\prime \prime} \mathrm{W}$, and at an altitude of $630 \mathrm{~m}$. Its population is 216 (96 women and $120 \mathrm{men}$ ), all are native residents from the region. The land is privately owned. San Pedro Altepepan is located at $19^{\circ} 53^{\prime} 44^{\prime \prime} \mathrm{N}$ and $97^{\circ} 02^{\prime} 15^{\prime \prime} \mathrm{W}$, and at an altitude of $764 \mathrm{~m}$. Its population is 312 inhabitants (146 women and $166 \mathrm{men}$ ). El Quimite is nearby, at 19 $52^{\prime} 55^{\prime \prime} \mathrm{N}$ and $97^{\circ} 02^{\prime} 00^{\prime \prime} \mathrm{W}$, at $876 \mathrm{~m}$. Its population is 335 inhabitants ( 157 women and $178 \mathrm{men}$ ).

The land in the last two villages functions under the ejido system (communal land under the perpetual stewardship of rural people for agricultural activities). Eighty and sixty percent of the inhabitants are originally from San Pedro and El Quimite, respectively, while the others come from other communities.

In La Vega there are no public health services, so the inhabitants use traditional medicine to treat and cure illnesses. Another characteristic of this village is that the road to the nearest urban zone is in poor conditions, making access difficult. 
Burgos-Hernández et al.: Potentially useful flora from the tropical rainforest, Veracruz, Mexico

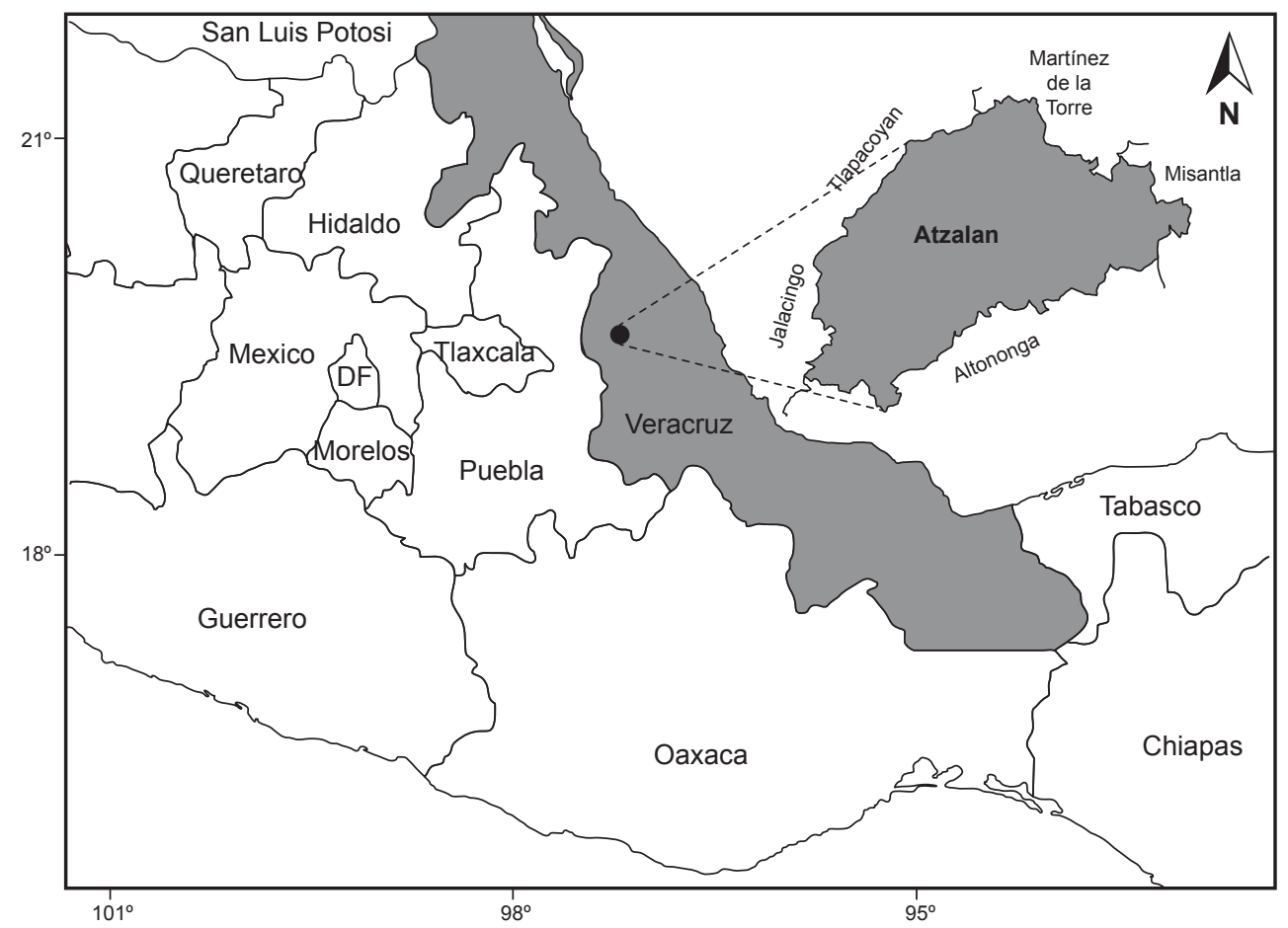

Fig. 1. Location of the municipality of Atzalan in the central region of the state of Veracruz, Mexico.

More than $90 \%$ of the homes are built of wood and there is no municipal wastewater drainage or drinking water services. The situation is different in San Pedro and El Quimite where there are health clinics and a greater dependence on allopathic medicine. Thus, the knowledge of traditional concepts and practices has changed, as modern medicine offers a greater number of treatments for illnesses. In many cases, traditional medicine has been almost completely replaced by allopathic medicine. Additionally, the road between these two villages and the nearest urban centers is better than that of La Vega, resulting in more road traffic.

Agriculture is the main economic activity in these localities. Corn, beans and coffee are the main crops, followed by bananas. Although most of the crops are for self-consumption, part of the production is sold commercially. It is notable that $90 \%$ of the people interviewed depend entirely on their farm and farm products for their survival. However, considering the limited opportunities for making a living in the 
countryside, many of the inhabitants migrate, which results in a loss of interest and knowledge regarding plant resources.

\section{Plant species inventory}

The sampling area was determined by using maps, aerial orthophotos and field surveys to identify the location of tropical rainforest fragments and the surrounding secondary vegetation areas. We selected the only two fragments of tropical rainforest with no apparent human disturbance, along with three patches of secondary vegetation at different stages of regeneration $(3,8$ and 15 years after abandonment according to the local people and vegetation composition) in order to evaluate vegetation use by the local inhabitants at its different stages. After this, we contacted the municipal authorities and community inhabitants to obtain permission to carry out the project. The sampling method by plot was used to assess the flora (Castillo-Campos et al., 2008). Twelve $100 \mathrm{~m}^{2}(10 \times 10 \mathrm{~m})$ plots were set up in each forest fragment and regeneration stages of secondary vegetation to inventory the trees and shrubs. Within each plot, three $4 \mathrm{~m}^{2}(2 \times 2 \mathrm{~m})$ plots were randomly placed for sampling the herbaceous plants. In the 8-year-old patch of secondary vegetation, there were only eight plots due to its small size. The total area sampled was $5600 \mathrm{~m}^{2}$. To determine the proportion of inventoried species richness according to sampling effort, we used the following equation of the Clench model (Guevara and Dirzo, 1998): $t q=\mathrm{q} /(\mathrm{b}(1-\mathrm{q}))$, where: $\mathrm{q}=\mathrm{Sn} /(\mathrm{a} / \mathrm{b})(\mathrm{a}=$ growth rate of new species; $b=$ parameter related to the shape of the curve; $\mathrm{Sn}=$ probability of finding a species). $b=$ parameter related to the shape of the curve (JiménezValverde and Hortal, 2003). Considering that the calculation of the inventoried portion of the total of the species in one zone must be greater than $70 \%$, a proportion of $80 \%$ was considered for this study $(t q=0.8)$.

Each plant species within the plots was identified and its canopy cover was recorded. Plant canopy was measured using the cover-abundance scale of Braun-Blanquet modified by van der Maarel (1979) that includes the following categories according to the percentage of coverage: 1 (1-3 individuals and less than 5\% coverage), 2 (4-10 individuals and less than 5\%), 3 (more than 10 individuals and less than 5\% ), 4 (less than 5\% and not abundant), 5 (5-12.5\%), 6 (12.6-25\%), 7 (25.1-50\%), 8 (50.1-75\%), $9(75.1-100 \%)$. One individual from each species was sampled as voucher specimen. Vouchers are deposited at the herbarium XAL of the Instituto de Ecología A. C.

Ethnobotanical analysis

To understand the socio-economic background of informants and to identify the value and management of the rainforest from the perspective of the local popula- 
Burgos-Hernández et al.: Potentially useful flora from the tropical rainforest, Veracruz, Mexico

tion, as well as the current and potential use of the floristic resources, we completed 10 semi-structured interviews in each village, 30 in total. The interviews consisted of 38 questions and were focused on socio-demographic information, conservation and tropical forest values (esthetic, economical and environmental), knowledge and management of plant resources. Respondents were 15 men and 15 women, ranging from 32 to 90 years old. The interviewees living close to the rainforest fragments are mainly farmers and were referred to us by the local authorities as land owners. The sample is non-statistical. However, the number of interviews was set up by using Bertaux's (1993) sample saturation criterion (i.e., when people do not provide new data and the information is repeated, it is considered that sufficient and representative data have been collected). The data obtained were subjected to a qualitative analysis to determine patterns of plant use and general points of view on this matter. Additionally, contingency tables ( $\chi^{2}$ test) were carried out to identify differences in knowledge of useful flora and the use of flora among villages, men and women and the age of the interviewees. In the last case, the participants were divided according to age into the following groups: $31-50,51-70$ and $71-100$ years. Furthermore, Spearman's rank correlation test was used to assess the correlation between age groups and their knowledge of plants.

Moreover, to analyze the use of the flora, the "Use Value" (UV) was calculated, using the method of summary of uses (Sánchez et al., 2001), where each category of use is assigned a value of one (1). So, the UV for a species is the number of uses and categories mentioned by the people. We defined thirteen categories of use: condiment, construction, food, forage, fuel, handicrafts, medicinal, ornamental, production, ritual, timber, tool making and others.

In order to evaluate the relationship between the UV of the species and their ecological importance, we calculated an index of adjusted ecological importance value (AEIV), using the importance value index suggested by Lamprecht (1990) and modified for the purposes of this study. The AEIV is the sum of the relative frequency values (number of plots in which a species is recorded / the sum of all frequencies $\times 100$ ) and cover (the sum of all the cover values for a species / the sum of the cover values for all species $\times 100$ ). The data collected were analyzed with Kendall's correlation $(P<0.05)$ using the program R 2.6.1.

Potentially useful flora

Potentially useful species are those plants which by their morphological characteristics (e. g. flower color, height, shape, fruits, etc.) might be useful in the diverse activities carried out by people and that have not yet been discovered by the local 
population. Other potentially useful plants include those species which current or potential use has been reported in the literature, but which have not been documented as such locally.

To identify potential flora, a thorough literature search was performed, focusing on the uses recorded for the species in our inventory. These species and their uses were checked against those mentioned by the interviewees to avoid duplicating entries. For some of the species included in the list of useful local plants, the uses mentioned in the literature were different from those mentioned by the local inhabitants; these were considered potentially useful and they were included in the final list of useful species.

From the species in the inventory which were missing any record of their use either in the literature or by the local population, species with potential as ornamental, live fences and shade plants were selected. These categories were chosen based on the opinion of respondents, appealing economical attraction for them, as well as visual aspects and plant morphology. The potential ornamental value was determined based on an analysis of the morphological and anatomical description of each plant, using the parameters proposed by Leszczyñska-Borys (1990): shape and structure (architecture) of the entire plant, foliage, flowers and fruit. To identify the species with potential as living fences or shade plants, the criteria used were: woody, mainly trees with structures that favor the presence of wildlife (i.e., fruit, flowers, etc.), not toxic to livestock, as well as their growth and stem regeneration.

\section{RESULTS AND DISCUSSION}

Plant species inventory

We recorded 338 species belonging to 210 genera and 89 families over a total sampling area of 0.56 ha (Table 1). Of this number, 117 species were exclusive of the rainforest, 109 of the secondary vegetation areas, and the remaining 112 occur in both plant communities.

The tropical rainforest is home to the largest number of species, genera and families. For this type of vegetation $85 \%$ of the flora $(t q=0.85)$ was inventoried according to the equation of species proportion. For the secondary vegetation areas, a total of the $90 \%(t q=0.9)$ of the plant species was inventoried in the three states of regeneration of the vegetation.

The total number of species recorded is higher, compared to that reported for the Lacandona region by Levy et al. (2000). These authors recorded a total of 757 
Burgos-Hernández et al.: Potentially useful flora from the tropical rainforest, Veracruz, Mexico

Table 1. Plant species richness by plant community

\begin{tabular}{lcccc}
\hline & Area sampled & No. of families & No. of genera & No. of species \\
\hline Tropical rainforest & $2400 \mathrm{~m}^{2}$ & 77 & 145 & 219 \\
Secondary vegetation & $3200 \mathrm{~m}^{2}$ & 65 & 136 & 188 \\
15 years old & $1200 \mathrm{~m}^{2}$ & 46 & 77 & 112 \\
8 years old & $800 \mathrm{~m}^{2}$ & 45 & 78 & 89 \\
3 years old & $1200 \mathrm{~m}^{2}$ & 32 & 57 & 67 \\
\hline Total & $5600 \mathrm{~m}^{2}$ & 89 & 210 & 338 \\
\hline
\end{tabular}

species in 5.7 ha (144 plots, each $400 \mathrm{~m}^{2}$ ) regarding tropical rainforest and secondary vegetation areas at different stages of regeneration and using a similar methodology. On a smaller area, in this study, we recorded a $40 \%$ of the flora reported for the Lacandona region by Levy et al. (2000). This does not only shows the high plant species richness that is still found in the fragments of the Atzalan rainforest (Table 1), but also in the secondary vegetation -at least under the prevailing conditions in this region- and their potential for the conservation of tropical plant diversity.

Ethnobotanical analysis

Local use of the flora. A total of 160 useful plants, known locally, were recorded. These represent $47 \%$ of the flora inventoried, belonging to 123 genera and 67 families, and emphasizing the family Piperaceae as the most dominant one. According to Gómez-Pompa (1966) and Scott et al. (2008), some species of this family are commonly used as ornamentals plants (mainly Peperomia), they are also used in traditional medicine, and as condiments (e.g., several species of Piper, with P. auritum as the most common). Four hundred and twenty two different uses in total were identified and grouped into 13 different categories (Table 2). The medicine category had the highest number of species and uses. Many of these species may potentially be incorporated in pharmaceutical industry (Balick and Mendelsohn, 1992). So, these species may represent a new source of income, compatible with the rainforest conservation.

Regarding the origin of products, the rainforest is the main provider of wood $(16 \%)$, food (14\%), fuel and construction material $(13 \%)$. Secondary vegetation areas mainly provide medicinal products $(28 \%)$ and forage $(8 \%)$. The timber species used for food and fuel are found in both environments (Table 2).

Twelve species had a high use value (UV $=4$ and 5) and these were found in both, the rainforest and the secondary vegetation. The species with high use values 
Table 2. Number of uses and species per category and percentage of useful species per plant community. SV (percentage of useful species unique for secondary vegetation); TRF (percentage of useful species unique for tropical rainforest); SV/TRF (percentage of useful species found in both communities).

\begin{tabular}{lccrrr}
\hline Category & No. of species & No. of uses & \multicolumn{1}{c}{ SV } & TRF & SV/TRF \\
\hline Timber & 30 & 45 & $13 \%$ & $16 \%$ & $19 \%$ \\
Food & 31 & 49 & $11 \%$ & $14 \%$ & $18 \%$ \\
Condiments & 4 & 4 & $3 \%$ & 0 & $1 \%$ \\
Ornamental & 4 & 7 & $3 \%$ & $3 \%$ & $1 \%$ \\
Medicinal & 52 & 175 & $28 \%$ & $17 \%$ & $19 \%$ \\
Work instrument & 8 & 9 & $1 \%$ & $8 \%$ & $3 \%$ \\
Handicrafts & 1 & 3 & $1 \%$ & 0 & $1 \%$ \\
Fuel & 25 & 35 & $10 \%$ & $13 \%$ & $15 \%$ \\
Construction & 21 & 46 & $10 \%$ & $13 \%$ & $9 \%$ \\
Ritual & 1 & 1 & 0 & 0 & $1 \%$ \\
Production & 2 & 3 & $2 \%$ & 0 & $1 \%$ \\
Forage & 7 & 13 & $8 \%$ & $2 \%$ & $1 \%$ \\
Other & 14 & 33 & $10 \%$ & $14 \%$ & $11 \%$ \\
\hline Total & 200 & 422 & $100 \%$ & $100 \%$ & $100 \%$ \\
\hline
\end{tabular}

are mainly used as timber and fuel, while those with a lower UV are mostly used as medicinal or food.

Ten species scored high (i.e. $>3$ ) using the index of adjusted ecological importance value (AEIV), and, from these, Heliconia wagneriana, Calatola mollis and Syngonium podophyllum had values greater than 5 (Fig. 2). These three species are widely spread, the first one, in secondary vegetation areas, the second in rainforest fragments, whereas $S$. podophyllum occurs in both plant communities. However, only $H$. wagneriana was recorded for local use, with a low score use value (UV $=1)$. Finally, the most used species are not necessarily those with the greatest ecological importance. Kendall's rank analysis indicated that there was no correlation between the AEIV and UV of species $(z=1.68, P=0.09154)$.

Galeano (2000) and Marín-Corba et al. (2005) state that the UV can reflect a greater number of records by the interviewees than the true use value of a species. Thus the UV would be measuring multi-use species more than their true value to the community. This represents a bias, as it occurs with the medicinal or the timber species which although there are only a few of them and they have a low use value 
Burgos-Hernández et al.: Potentially useful flora from the tropical rainforest, Veracruz, Mexico

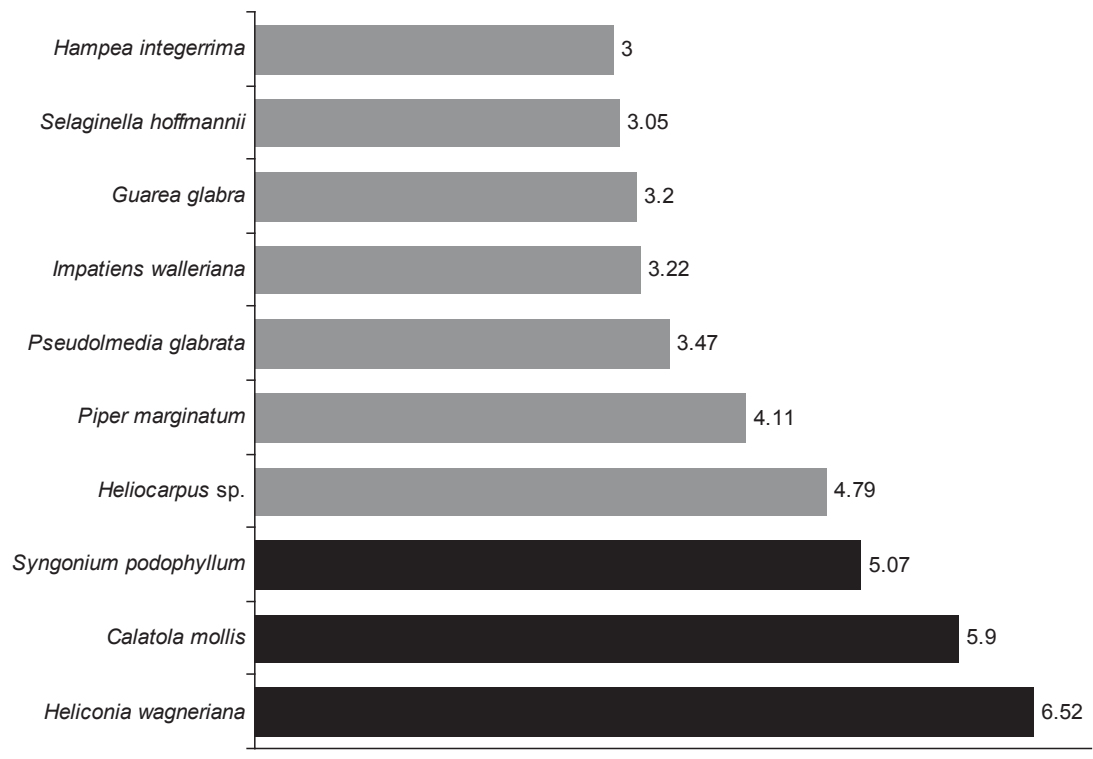

Fig. 2. Comparison of index of adjusted ecological importance value (AEIV) for the species with the highest values. The three species with a AEIV $>5$ are shaded in black.

(1), they are very important to the local population owing to their specific use. In this context, it is possible to distinguish the following terms:

a) Degree of usefulness of one species or species multi-use, this is the number of uses of a species regardless of their quality or importance to people, which would actually measure the use value. For example: Magnolia mexicana $(\mathrm{UV}=4)$, which is used not only as timber, but also as food, medicine and as a condiment.

b) Importance of the species or use value. This is the real value of a species, because although a species might have a single use, it is of paramount importance for the local population. This applies to Oecopetalum mexicanum, which even though its UV is low (1), it has a great importance in the families' diet.

c) Species use. Examples are many of the timber species, which in spite of their poor quality and the low durability are still used because of their availability and abundance, given the scarcity of higher quality species which could be used instead. 
The first two terms are not determined by the abundance, frequency or availability of the species, but by the quality of the product and, where applicable, the number of uses and products that can be obtained from them. Particularly, the adoption of the term of importance of the species allows us to consider multiple uses, quality and the actual transcendence of species in people's subsistence.

As for life forms, the trees and herbaceous are the most used plants at 35\% each. In the rainforest, useful tree species are as numerous as the herbaceous ones, while in secondary vegetation areas, the useful herbaceous are more numerous than useful trees. This is consistent with data reported by different studies about the plants in Mexico (Aguilar et al., 1994; Shackleton and Shackleton, 2004; Levy et al., 2006). This proportion may be a result of occurrence frequency of these biological forms in nature. Additionally, it is also likely that this outcome is related to the high number of species of the Fabaceae and Asteraceae families. According to Caballero et al. (1998) and more recently to Thomas et al. (2009), the useful species of these two families are probably more numerous than in any other botanical family.

Local knowledge of useful plants. From the 160 useful species identified, residents at La Vega use 100\% of them, 98\% of them in El Quimite, and 90\% in San Pedro (no significant difference: $\chi^{2}=0.442,2$ d.f., $P=0.8017$ ). Overall, there was no significant difference between genders and their knowledge of the number of useful plants $\left(\chi^{2}=4.499,2\right.$ d.f., $\left.P=0.1054\right)$. However, certain patterns were identified in La Vega as well as in El Quimite, where the men interviewed seemed to be more knowledgeable regarding the number and uses of plants than women. This is understandable if we consider that men know more about timber species, while women know more about medicinal plants. These differences have been partly explained as a consequence of the sexual division of labor in traditional societies (MüllerSchwarze, 2006). In this sense, Cadena Vargas et al. (2006) observed that a smaller number of species was reported by women than by men. In San Pedro, women had more knowledge of the useful species. This could be due to the constant male migration; according to in situ observation and interviewees, in San Pedro, there has been an increase in activities carried out by women in both, the field and also at home. Therefore, they have greater knowledge of local flora.

Moreover, it is important to notice that during the study, local people mentioned that the lack of access to secondary school, high school and college causes migration of young people, looking for opportunities of a better education, thus adopting the urban lifestyle and its practices. Alba (2004) states that those who go to work in the cities become more involved in the outside world and tend to give up 
Burgos-Hernández et al.: Potentially useful flora from the tropical rainforest, Veracruz, Mexico

some of the customs of their home community and traditional production techniques when they join the transnational job market. Over time, these patterns make people replace their traditions, and consequently knowledge and local traditions are getting lost (Namo, 2003).

Regarding the effect of the age of the interviewees, there were no significant differences and correlation between the interviewee's age groups and their knowledge of the useful flora $\left(\chi^{2}=1.22,2\right.$ d.f., $P=0.5429$; Spearman, $\left.\mathrm{r}=0.024, P=0.85\right)$. However, and again, we identified that older inhabitants are much more familiar with a larger number of useful species than their younger counterparts. Of the 30 interviews, three people ranging between 71 to 100 years old mentioned 68 useful plants on average ( \pm 25.4$), 13$ people ranging 51 to 70 years old mentioned 54 species $( \pm 25.3$ ) and 14 people ranging 31 to 50 years old mentioned 51 species $( \pm 20.9)$. These results match with those of Cadena Vargas et al. (2006) who found that the mean number of useful species known by age groups was greater among the older inhabitants. This confirms the assertion of Phillips and Gentry (1993) and Case et al. (2005), who mention that most of the traditional knowledge is based on older people's experience. However, in our study, the lack of differences among groups may indicate that age is not the only factor that affects knowledge of useful local flora. One possible explanation for this is that people not originally from the area are not as familiarized with the useful species as those who have lived there all their lives.

Given the results of our observations, it is possible to say that out of the three villages studied, La Vega has the most knowledgeable population in regards of the flora, its uses and values. One of the reasons supporting this assertion is that the limited communication between this and other villages has in a way, favored the population in preserving this knowledge. This supports the hypothesis of Levy et al. (1997) and Case et al. (2005) that local knowledge of botany increases with increasing geographic isolation, as does the preservation of traditional knowledge of botany. Thus, it is in the more isolated sites where the flora is used more frequently and intensively, as indicated by our results. Paradoxically, La Vega is the village most likely to lose its rainforest since $90 \%$ of the inhabitants think that it is necessary to cut down part of the rainforest to make way for orchards. This idea is a direct reflection of the precarious economic situation of this village. Although they recognize the importance of the rainforest, the economic pressure makes the deforestation necessary, in order for them to be able to plant and harvest crops, thus improving their economic situation. Ecological and social changes produced by economic and technological change have resulted in a profound transformation in the value assigned to plants (Case et al., 2005; Quinlan and Quinlan, 2007). 
It is necessary to emphasize that we are in no way suggesting that rural communities should be deprived of education opportunities, or remain isolated from urban areas, but rather the opposite; we would like to see a different approach towards education, where local knowledge is valued and younger generations are encouraged to preserve it, as they also learn and apply scientific principles. This would contribute to the rational use of the environment and the continued stewardship of traditional knowledge and practices.

Potentially useful plants. From the literature, a total of 40 potentially useful species were identified. Added to the 160 locally used species, this gives a total of 200 species with at least one use recorded. These 200 species belong to 148 genera and 69 families (Appendix), which represent 59\% of the flora we inventoried. The Piperaceae family was the best represented, with 13 species, followed by Asteraceae and Euphorbiaceae, with 11 and nine species respectively, and Fabaceae (six). The most frequent genera were Piper (eight species) and Tillandsia (five). Of the 200 useful species, 39 of them had potential uses not previously recorded in literature: 19 of them as ornamentals, 22 as living fences and nine for crop shade.

Of the 160 locally known useful species, $60 \%$ have other uses in addition to those mentioned by the interviewees, and these species were therefore considered potentially useful to the local population. There was no use associated with $38 \%$ of the inventoried flora in the literature or even by the interviewees. Of this subset of the flora, 18 species are potentially useful as ornamentals, living fences and shade plants. These plants belong to 13 genera and 10 families, of which the family Araceae had the most representatives.

The enormous ornamental potential of the flora recorded is noteworthy and, once its reproductive efficiency and propagation mechanisms are known, these species could be considered for domestication and introduction into the market for commercialization. Ibarra et al. (1997), Mejía and Espinosa et al. (2003), Ramírez (2005), Corona NavaEsparza and Chimal (2006), Rendón (2007) and Munguia-Lino et al. (2010) present a clear case of the importance of phytogenetic resources in Mexico, and particularly of cultivated ornamentals, cultivated native species and those with potential for cultivation. Only in the Tuxtla region $12.4 \%$ of all flowering plant species are orchids, with a highly value in the market (Ibarra et al., 1997). Rzedowski (1995) states that Mexico produces around 40 ornamental species for which there is worldwide demand, and that 300 ornamental species are planted in public and family gardens, as well as along the streets of Mexico, although they do not appear in any horticultural catalog. There are an estimated 1,000 ornamental Mexican species being used and a further 1,000 with potential for use, 
resulting in a total of 2,000 cultivated ornamental species (Rzedowski, 1995). Mexico, not surprisingly, is therefore characterized as a country that makes ample use of its ornamental resources. However, the national inventory has not yet been finished and the state of conservation of the flora has not yet been evaluated satisfactorily.

We recorded 27 species with the potential to be used as living fences. In the State of Veracruz, Avendaño and Acosta (2000) recorded 218 species of vascular plants with this use. Of these, $9 \%$ are introduced and $88 \%$ of them have other uses as well; the trees were the most used life form and the legumes the best represented family. Those species are also commonly used for other important purposes such as food, forage, medicine, ornamentation, construction, fuel and for beekeeping (Avendaño and Acosta, 2000; Pinto-Ruiz et al., 2010). In this study, several of the species proposed as living fences and crop shade are mainly used for timber and food. The incorporation of the potentially useful species of the rainforest into local productive systems is now crucial in order to ensure their use and conservation in the long term.

\section{ACKNOWLEDGEMENTS}

We extend our thanks to the people of San Pedro, La Vega and El Quimite for their collaboration and support during this project. We are grateful to Javier Laborde Dovalí for his comments on the manuscript, Roger Guevara Hernández for his assisted with the statistical analysis and Javier Barrientos Villalobos for support in image editing. Arturo Gómez Pompa sowed the first seed of this research.. We thank Lamberto Aragón Axomulco, Jesús Pale Pale and Julia Hernández Villa for helping with the field work. We extend our thanks to Kristyna Baloghova and Salvador Guerra to revise the English of the manuscript.

\section{LITERATURE CITED}

Alba, F. 2004. El Tratado de Libre Comercio, la migración y las políticas migratorias. In: Casares, R. and H. Sorbazo (eds.). Diez años del TLCAN en México, una perspectiva analítica. Fondo de Cultura Económica. Mexico, D.F., Mexico. pp. 215-242.

Aguilar, A., J. R. Camacho, S. Chino, P. Jacquez and M. E. López. 1994. Herbario medicinal del IMSS. Información etnobotánica. Instituto Mexicano del Seguro Social. Mexico, D.F., Mexico. 253 pp.

Anonymous, 2007. Secretaría de Medio Ambiente y Recursos Naturales. http://www. semarnat.gob.mx/Pages/Inicio.aspx 
Avendaño, S. and I. Acosta. 2000. Plantas utilizadas como cercas vivas en el estado de Veracruz. Madera y Bosques 6: 55-71.

Balick, M. J. and R. Mendelsohn. 1992. Assessing the economic value of traditional medicines from tropical rain forest. Conserv. Biol. 6: 128-130

Bawa, K. S., W. J. Kress, M. N. Nadkarni and S. Lele. 2004. Beyond paradise-meeting the challenges in tropical biology in the $21^{\text {st }}$ century. Biotropica 36 : 437-446.

Bertaux, D. 1993. Los relatos de vida en el análisis social. In: Aceves Lozano, J. (ed.). Historial y fuente oral. Instituto de Investigaciones Dr. José Maria Mora-Universidad Nacional Autónoma de México. Mexico, D.F., Mexico. pp. 136-148.

Burgos-Hernández, M. 2007. Comparación de la riqueza de especies de flora vascular en dos unidades del paisaje en el municipio de Atzalan, Veracruz. Thesis. Universidad Autónoma Metropolitana. Unidad Xochimilco. Mexico, D.F. Mexico. 44 pp.

Caballero, J., A. Casas, L. Cortes and C. Mapes. 1998. Patrones en el conocimiento, uso y manejo de las plantas en pueblos indígenas de México. Estudios Atacameños 16: 181-195.

Cadena Vargas, C., M. Díazgranados Cadelo, and H. Bernal Malagón. 2006. Plantas útiles para la elaboración de artesanías de la comunidad indígena monifue amena (Amazonas, Colombia). Universitas Scientiarum 12: 97-116.

Case, J. R., G. F. Paulli and D. D. Soejarto. 2005. Factors in maintaining indigenous knowledge among ethnic communities of Manus Island. Econ. Bot. 59: 356-365.

Castillo-Campos, G., G. Halffter and C. E. Moreno. 2008. Primary and secondary vegetation patches as contributors to floristic diversity in a tropical deciduous forest landscape. Biodivers. Conserv. 17: 1701-1714.

Corona Nava-Esparza, V. and H. A. Chimal. 2006. Plantas mexicanas con potencial ornamental. Universidad Autónoma Metropolitana, División de Ciencias Biológicas de la Salud, Serie Académicos CBS 60. Mexico, D.F. Mexico. 626 pp.

Cronquist, A. 1988. The evolution and classification of flowering plants. The New York Botanical Garden. New York, USA. 1968 pp.

Díaz-Gallegos, J. R., M. Jean-François and A. Velázquez. 2010. Trends of tropical deforestation in Southeast Mexico. Singap. J. Trop. Geo. 31: 180-196.

Delvaux, C., B. Sinsin, F. Darchambeau and P. Van Damme. 2009. Recovery from bark harvesting of 12 medicinal tree species in Benin, West Africa. J. App. Ecol. 46: 703712 .

Espejo-Serna, A., A. R. López-Ferrari and I. Ramírez-Morillo. 2005. Bromeliaceae. Fascículo 136. In: Sosa, V. \& A. Gómez-Pompa (eds.). Flora de Veracruz, Instituto de Ecología, A.C. Xalapa, Mexico. pp. 307.

Espinosa, F. A., R. H. González and M. J. Mejía. 2003. La comercialización de plantas en peligro de extinción. In: Mejía M. J. and F. A. Espinosa (eds.). Plantas nativas de México con potencial ornamental. Universidad Autónoma de Chapingo. Estado de Mexico, Mexico. pp. 199-217.

Galeano, G. 2000. Forest use at the Pacific Coast of Choco, Colombia: a quantitative approach. Econ. Bot. 54: 358-376.

Gómez-Pompa, A. 1966. Estudios botánicos en la región Misantla, Veracruz. Instituto Mexicano de Recursos Naturales Renovables. Mexico, D.F., Mexico. 173 pp. 
Burgos-Hernández et al.: Potentially useful flora from the tropical rainforest, Veracruz, Mexico

Guevara, R. and R. Dirzo. 1998. A rapid method for the assessment of the macromycota. The fungal community of an evergreen cloud forest as an example. Can. J. Bot. 76(4): 596-601.

Guevara, S. and A. Lira-Noriega. 2004. De los pastos de la selva a la selva de los pastos: la introducción de la ganadería en México. Pastos 34: 109-150.

Ibarra-Manríquez, G., M. Ricker, G. Angeles, S. Sinaca and M. A. Sinaca. 1997. Useful plants of the Los Tuxtlas rain forest (Veracruz, México): considerations of their market potential. Econ. Bot. 51: 362-376.

Jiménez-Valverde, A. and J. Hortal. 2003. Las curvas de acumulación de especies y la necesidad de evaluar la calidad de los inventarios biológicos. Rev. Ibé. Aracnol. 8:151-161.

Lamprecht, H. 1990. Silvicultura en los trópicos. Los ecosistemas forestales en los bosques tropicales y sus especies arbóreas, posibilidades y métodos para un aprovechamiento sostenido. Eschborn, GTZ. Rossdorf, Germany. 335 pp.

Leszczyñska-Borys, H. 1990. Introducción a la horticultura ornamental. Universidad Popular Autónoma del Estado de Puebla. Escuela de Fitotecnia. Puebla, Mexico. 42 pp.

Levy, A., A. D. Brown, H. R. Grau and A. Grau. 1997. Local knowledge and the use of plants in rural communities in the montane forest of northwestern Argentina. Managing fragile ecosystems in the Andes. Mt. Res. Dev. 17: 263-271.

Levy, S. I., F. A. Durán and C. D. Sánchez. 2000. Contribución al conocimiento de la flora útil de la selva Lacandona. Conservación Internacional México A. C. Tuxtla Gutiérrez, Mexico. 32 pp.

Levy, S. I., J. R. Aguirre Rivera, J. D. García Pérez and M. M. Martínez Romero. 2006. Aspectos florísticos de Lacanhá Chansayab, Selva Lacandona, Chiapas. Act. Bot. Mex. 77: 69-98

Marín-Corba, C., D. Cárdenas-López and S. Suárez-Suárez. 2005. Utilidad del valor de uso en etnobotánica. Estudio en el Departamento de Putumayo (Colombia). Caldasia 27(1): 89-101.

Mejía, M. J. and F. A. Espinosa. 2003. Plantas nativas de México con potencial ornamental. Universidad Autónoma de Chihuahua. Chihuahua, Mexico. 217 pp.

Mickel, J. T. and A. R. Smith. 2004. The Pteridophytes of Mexico. Memoirs of the New York Botanical Garden Press. Vol. 88. New York, U.S.A. 1054 pp.

Mirjam, A. F., Ros-Tonen and K. F. Wiersum. 2005. The scope for improving rural livelihoods through non-timber forest products: an evolving research agenda. Forests, Trees and Livelihoods 15: 129-148.

Müller-Schwarze, N. K. 2006. Knowledge and categorization as adaptations to life in Panama in the twenty-first century. Econ. Bot. 60: 321-334.

Munguía-Lino, G., L. M. Vázquez-García and J. A. López-Sandoval. 2010. Plantas silvestres ornamentales comercializadas en los mercados de la flor de Tenalcingo y Jamaica, México. Polibotánica 29: 281-308.

Namo, M. G. 2003. Nuevas propuestas para la gestión educativa. Modelo de gestión para la satisfacción de las necesidades básicas de aprendizaje. Dirección General de Materiales y Métodos Educativos de la Subsecretaria de Educación Básica y Normal. Secretaría de Educación Pública. Mexico, D.F. Mexico. 119 pp.

Phillips, O. and A. H. Gentry. 1993. The useful plants of Tambopata, Perú: I. Statistical hypothesis tests with a new quantitative technique. Econ. Bot. 47(19): 15-32. 
Pinto-Ruiz, R., D. Hernández, H. Gómez, M.A. Cobos, R. Quiroga and D. Pezo 2010. Árboles forrajeros de tres regiones ganaderas de Chiapas, México: usos y características nutricionales. Universidad y Ciencia 26: 19-31.

Quinlan, M. B. and R. J. Quinlan. 2007. Modernization and medicinal plant knowledge in a Caribbean horticultural village. Med. Anthropol. Q. 21(2): 169-192.

Ramírez, H. S. G. 2005. Las Acanthaceae de Tabasco y su potencial como plantas ornamentales. Thesis. Universidad Juárez Autónoma de Tabasco. Tabasco, Mexico. 119 pp.

Rendón, A. 2007. Plantas con potencial uso ornamental del Estado de Morelos. Thesis. Escuela Nacional de Ciencias Biológicas del Instituto Politécnico Nacional. Mexico, D.F., Mexico. 240 pp.

Rzedowski, J. 1995. Aspectos de las plantas ornamentales de México. Revista Chapingo. Serie Horticultura 1: 5-7.

Sánchez, M., A. Duque, P. Miraña, E. Miraña and J. Miraña. 2001. Valoración del uso no comercial del bosque. Métodos en etnobotánica cuantitativa. In: Duivenvoorden, J., H. Balslev, J. Cavelier, C. Grandez, H. Tuomisto and R. Valencia (eds.). Evaluación de recursos vegetales no maderables en la Amazonia noroccidental. Universiteit van Amsterdam. Amsterdam, The Netherlands. pp. 179-224.

Scott, I. M., H. R. Jensen, B. J .R. Philogène and J. T. Arnason. 2008. A review of Piper spp. (Piperaceae) phytochemistry, insecticidal activity and mode of action. Phytochem. Rev. 7: 65-75.

Shackleton, C. M. and S. E. Shackleton. 2004. The importance of non-timber forest products in rural livelihood security and as safety nets: a review of evidence from South Africa. S. Afr. J. Sci. 100: 658-664.

Sosa, V. and A. Gómez-Pompa (comps.). 1994. Lista Florística. Fascículo 82. In: Sosa, V. and A. Gómez-Pompa (eds.). Flora de Veracruz. Instituto de Ecología, A.C., Xalapa, Mexico. pp. 245.

Steffan-Dewenter, M. Kessler, J. Barkmann, M. M. Bos, D. Buchori, S. Erasmi, H. Faust, G. Gerold, K. Glenk, S. R. Gradstein, E. Guhardja, M. Harteveld, D. Hertel, P. Ho, M. Kappas, S. K. Hler, C. L., M. Maertens, R. Marggraf, S. Migge-Kleian, J. Mogea, R. Pitopang, M. Schaefer, S. Schwarze, S. G. Sporn, A. Steingrebe, S. S. Tjitrosoedirdjo, S. Tjitrosoemito, A. Twele, R. Weber, L. Woltmann, M. Zeller and T. Tscharntke. 2007. Tradeoffs between income, biodiversity, and ecosystem functioning during tropical rainforest conversion and agroforestry intensification. PNAS 104: 4973-4978.

Thomas, E., I. Vandebroekb, S. Sancac and P. V. Dammea. 2009. Cultural significance of medicinal plant families and species among Quechua. J. Ethnopharmacol. 122: 60-67.

Ticktin, J. 2004. The ecological implications of harvesting non-timber forest products. J. Appl. Ecol. 41: 11-21.

van der Maarel, E. 1979. Transformation of cover-abundance values in phytosociology and its effects on community similarity. Vegetatio 39: 97-114. 
Burgos-Hernández et al.: Potentially useful flora from the tropical rainforest, Veracruz, Mexico

\section{APPENDIX}

List of the useful flora and potentially useful flora of the tropical rainforest and secondary vegetation in the municipality of Atzalan, Veracruz

The Cronquist (1988) classification was followed for the floristic list. When this was not possible, we used the classification and species record in the "Flora de Veracruz" (Sosa and Gómez-Pompa, 1994), as well as the nomenclature used in the fascicles (v.gr., Espejo-Serna et al., 2005). For the Pteridophytes the nomenclature of Mickel and Smith (2004) was followed.

The order of the list is as follows: species; common name (only if applicable); life form; cultivation (only if applicable); uses; potentially useful (only if applicable). Life form: H (Herb), T (Tree), B (Shrub), C (Creeper), E (Epiphyte). CU (Cultivated). Uses: T (Timber), F (Food), C (Condiments), O (Ornamental), M (Medicinal), WI (Work instrument); HD (Handicrafts), FU (Fuel), CO (Construction), R (Ritual), P (Industry production), F (Forage), SP (Shade plant), LF (Living fence). PU (Potentially useful).

\section{PTERIDOPHYTES (PTERIDOPHYTA)}

\section{Aspleniaceae}

Asplenium africanum Desv.; pezma; $\mathrm{H} ; \mathrm{M}$

Asplenium sp.; pezma; $\mathrm{H}$; $\mathrm{CO}$

Blechnaceae

Blechnum glandulosum Kaulf. ex Link; pezma; $\mathrm{H} ; \mathrm{CO}$

Blechnum schiedeanum (Schltdl. ex C. Presl) Hieron.; pezma; $\mathrm{H}$; $\mathrm{CO}$

Woodwardia martinezii Maxon ex Weath.; pezma; $\mathrm{H}$; $\mathrm{CO}$

Cyatheaceae

Cyathea sp.; pezma, H, CO

Trichipteris schiedeana (C. Presl) R.M. Tryon; pezma; $\mathrm{H}$; $\mathrm{CO}$

Dryopteridaceae

Lastreopsis effusa (Sw.) Tindale; pezma; $\mathrm{H}$; $\mathrm{CO}$

Phanerophlebia sp.; pezmilla; $\mathrm{H}$; $\mathrm{CO}$

Marattiaceae

Marattia laxa Kunze; casco de burro; H; F, M

Pteridaceae

Adiantum braunii Mett. ex Kuhn; pezma; H; P
Hemionitis palmata $\mathrm{L} . ; \mathrm{H}$; PU: O

Pteris grandifolia L.; H, PU: O

Pteris sp.; pezma; $\mathrm{H}$; $\mathrm{CO}$

Selaginellaceae

Selaginella hoffmannii Hieron.; doradilla; H; M; PU: O

Selaginella stellata Spring; doradilla; H; M; PU: O

Thelypteridaceae

Cyclosorus dentatus (Forssk.) Ching; pezma; $\mathrm{H} ; \mathrm{CO}$

Thelypteris cf. ovata var. lindheimeri (C. Chr.) A.R. Sm.; pezma; H; CO

Thelypteris melanochlaena (C. Chr.) C.F. Reed; pezma; $\mathrm{H}$; $\mathrm{CO}$

Thelypteris mollis (Mett.) R.M. Tryon; pezma; $\mathrm{H} ; \mathrm{CO}$

\section{MONOCOTYLEDONS (LILIOPSIDA)}

\section{Araceae}

Anthurium schlechtendalii Kunth; malaste; H; PU: O 
Appendix. Continuation.

\section{Arecaceae}

Chamaedorea concolor Mart.; tepejilote; $\mathrm{H} ; \mathrm{O}$

Chamaedorea elegans Mart.; tepejilote; H; O, F

Bromeliaceae

Catopsis sp.; maguey de árbol; $\mathrm{C}$; O

Tillandsia concolor L.B. Sm.; zuchil; E; O

Tillandsia filifolia Schltdl. \& Cham.; zuchil; H; $\mathrm{O}$

Tillandsia flexuosa Sw.; zuchil; E; O

Tillandsia schiedeana Steud.; zuchitl chico; C;

$\mathrm{O}$

Tillandsia sp.; zuchitl grande; C; O

\section{Commelinaceae}

Commelina tuberosa L.; H; M, WI

Commelina diffusa Burm. f.; pashquelite; $\mathrm{H}$; F

Gibasis schiedeana (Kunth) D.R. Hunt; matalin; E; M

Costaceae

Costus dirzoi García-Mend. \& G. IbarraManr.; caña de venado; H; M, F; PU: O

Costus pictus D. Don; caña de venado; H; M, F; PU: O

Costus pulverulentus C. Presl; caña de venado; H; M, F; PU: O

Cyperaceae

Cyperus andinus Palla ex Kük.; H; F, O

Fimbristylis dichotoma (L.) Vahl; H; O

\section{Dioscoreaceae}

Dioscorea convolvulacea Schltdl. \& Cham.; papa cimarrona; $\mathrm{C} ; \mathrm{F}$

Dioscorea mexicana Scheidw.; barbasco; C; P

Heliconiaceae

Heliconia wagneriana Petersen; papatla; H; F, $\mathrm{O}$

\section{Poaceae}

Elytrigia repens (L.) Desv. ex Nevski; zacate; $\mathrm{H} ; \mathrm{M}, \mathrm{F}$

Ichnanthus nemorosus (Sw.) Döll.; zacate; H; FR

Lasiacis ligulata Hitchc. \& Chase; zacatillo; H; FR

Paspalum sp.; zacate; H; FR

Smilacaceae

Smilax aristolochiifolia Mill.; tecoatan; C; M, $\mathrm{CO}$
Smilax vanilliodora F.W. Apt.; alambrillo; C; M, F

Smilax sp;; chalcuahui; T; M

Zingiberaceae

Hedychium coronarium J. Koenig; papatilla; $\mathrm{H} ; \mathrm{O}$

Renealmia mexicana Klotzsch ex Petersen; tapiton; $\mathrm{C} ; \mathrm{F}$

\section{DICOTYLEDONS (MAGNOLIOPHYTA)}

\section{Acanthaceae}

Aphelandra scabra (Vahl) Sm.; C; LF

Justicia breviflora (Nees) Rusby; chinahuatillo; $\mathrm{H} ; \mathrm{M}$

\section{Actinidaceae}

Saurauia scabrida Hemsl.; marangola; T; CO, $\mathrm{F}$

\section{Amaranthaceae}

Amaranthus sp.; H; F, FU

Iresine diffusa Humb. \& Bonpl. ex Willd.; canilla de pollo; $\mathrm{C}$; $\mathrm{M}$

Anacardiaceae

Astronium graveolens Jacq.; chaca; T; M, FU, HD; PU: SP

Mangifera indica L.; mango; T; CU; F, M, O, SP

Toxicodendron radicans (L.) Kuntze; T; M

Spondias mombin L.; jobo; T; M, F, CO, T, WI, FU; PU: O

Annonaceae

Anaxagorea guatemalensis Standl.; platanillo; T; CO; PU: LF

Annona glabra L.; tentepo; B; F, M; PU: PS

Annona reticulata L.; anona; B; F, FU; PU: O

Cymbopetalum baillonii R.E. Fr.; platanillo; T; PU: O

Desmopsis trunciflora (Schltdl. \& Cham.) G.E.

Schatz.; huevillo de burro; B; M, FU, F; PU:

$\mathrm{O}$

Apocynaceae

Aclepias curassavica L.; H; M, WI

Stemmadenia litoralis (Kunth) L. Allorge; hue-

vo de gato; T; $M$

Tabernaemontana alba Mill.; B; O 
Burgos-Hernández et al.: Potentially useful flora from the tropical rainforest, Veracruz, Mexico

Appendix. Continuation.

Philodendron hederaceum (Jacq.) Schott; H, malaste, papelillo; C; PU: O

Philodendron inaequilaterum Liebm.; papelillo; H; PU: O

Philodendron radiatum Schott; papelillo; C; F; PU: O

Philodendron sagittifolium Liebm.; papelillo; C; F; PU: O

Syngonium neglectum Schott; malaste; C; PU: O

Syngonium podophyllum Schott; malaste; $\mathrm{H} ; \mathrm{O}$

Xanthosoma robustum Schott; mafafa; H; M, $\mathrm{F}, \mathrm{O}$

Araliaceae

Dendropanax arboreus (L.) Decne. \& Planch.; zapatillo, tamalcahuite; T; M, T, WI, HD

Asteraceae

Ageratum houstonianum Mill.; hierba de agua; $\mathrm{H} ; \mathrm{M}, \mathrm{WI}$

Artemisia sp.; necachamba; $\mathrm{H} ; \mathrm{M}$

Bidens pilosa L.; H; M, FU, WI

Critonia morifolia (Mill.) R. M. King \& H. Rob.; tabaquillo; T; M

Koanophyllon albicaule var. laxius B.L. Rob.; $\mathrm{H} ; \mathrm{M}$, WI

Melampodium americanum L.; acahual; B; FR

Melampodium longifolium Cerv. ex Cav.; hierba de cochino; H; FR

Mikania cordifolia (L. f.) Willd.; mozotillo; H; M

Mikania micrantha Kunth; C; M

Telanthophora arborescens (Steetz) H. Rob. \& Brettell; tabaquillo; $\mathrm{C}$; M

Vernonanthura patens (Kunth) H. Rob.; duraznillo; T; M, FU

\section{Balsaminaceae}

Impatiens walleriana Hook. f.; balsamina; $\mathrm{H}$; $\mathrm{O}, \mathrm{FR}$

\section{Begoniaceae}

Begonia glabra Aubl.; H; PU: O

Begonia nelumbiifolia Schltdl. \& Cham.; chocoyule de monte; $\mathrm{H}$; PU: O

Cannabaceae

Trema micrantha (L.) Blume; mata caballo; T; PU: LF, SP
Caricaceae

Vasconcellea cauliflora (Jacq.) A. DC.; papayo;

T; M; PU: O

\section{Celastraceae}

Rhacoma uragoga (Jacq.) Baill.; bejuco colorado; $\mathrm{C} ; \mathrm{M}$

\section{Chrysobalanaceae}

Licania platypus (Hemsl.) Fritsch; T; T, F, WI; PU: LF

\section{Clusiaceae}

Rheedia edulis (Seem.) Planch. \& Triana; manzanillo; T; FU, CO; PU: SP, LF

\section{Convolvulaceae}

Evolvulus prostratus B.L. Rob.; cola de pavo; $\mathrm{C} ; \mathrm{O}$

Ipomoea alba L.; cola de rata; C; FR

Ipomoea sp.; cola de rata; $\mathrm{C}$; FR

\section{Cucurbitaceae}

Hanburia mexicana Seem. EM.; chayomono; C; M, F

\section{Ebenaceae}

Diospyros nigra (J.F. Gmel.) Perr.; zapote negro; T; F, M, FU; PU: O, SP, LF

\section{Euphorbiaceae}

Acalypha sp.; escobilla; H; M

Alchornea latifolia Sw.; calabacillo; T; CO, WI, HD; PU: LF

Alchornea sp.; calabacillo; T; CO

Bernardia interrupta (Schltdl.) Müll. Arg.; mal hombre; B; M

Chamaesyce mesembryanthemifolia (Jacq.)

Dugand; H; M, WI

Cnidoscolus multilobus (Pax) I.M. Johnst.; ortiga, mala mujer; $\mathrm{B} ; \mathrm{M}$

Croton gossypiifolius Vahl; san gregado; B; CO, FU, M, SP; PU: LF

Jatropha curcas L.; H; M, O, SP

Sapium lateriflorum Hemsl.; chiclillo; T; FU

Fabaceae

Bauhinia sp.; casco de vaca, pata de vaca; B; $\mathrm{M}$

Desmodium frutescens Schindl.; cacahuatillo; $\mathrm{H} ; \mathrm{R}, \mathrm{M}, \mathrm{F}$ 
Appendix. Continuation.

\begin{tabular}{|c|c|}
\hline Gliricidia sepium (Jacq.) Kunth ex Walp.; T; M, & Miconia sp.; tezhuilla; B; FU, CO \\
\hline T, F, FU, WI, HD; PU: SP, LF & Miconia trinervia (Sw.) D. Don ex Loudon; \\
\hline Inga sp.; chalahuite; T; FU, F; PU: SP & tezhuilla \\
\hline $\begin{array}{l}\text { Lysiloma auritum (Schltdl.) Benth.; guajillo; T; } \\
\text { CO; PU: LF }\end{array}$ & $\begin{array}{l}\text { Tibouchina sp.; chocoyule; C; F, CO, WI } \\
\text { Meliaceae }\end{array}$ \\
\hline $\begin{array}{l}\text { Pithecellobium arboreum (L.) Urb.; frijolillo; } \\
\text { T; SP, WI }\end{array}$ & $\begin{array}{l}\text { Guarea glabra Vahl; azote; T; WI, CO, FU; } \\
\text { PU: LF }\end{array}$ \\
\hline Icacinaceae & Guarea sp.; rama tinaja; T; SP \\
\hline Calatola mollis Standl.; calatola; T; PU: O, SP, LF & Melia azederach L.; piocho; T; R, SP, O, CO, FU \\
\hline Oecopetalum mexicanum Greenm. \& C.H. & Moraceae \\
\hline Thomps.; cachichin; T; F, CO; PU: O, SP, LF & Chlorophora tinctoria (L.) Gaudich. ex Benth.; \\
\hline Lamiaceae & canelilla, moral; T; CO, FU, F, SP \\
\hline Ocimum basilicum L.; H; M, C & Ficus calyculata Mill.; T; PU: SP, LF \\
\hline Lauraceae & Ficus lapathifolia (Liebm.) Miq.; higuera blan- \\
\hline $\begin{array}{l}\text { Beilschmiedia anay (S.F. Blake) Kosterm.; ana- } \\
\text { yo, escalan; T; CO, F, SP, FU; PU: O, LF }\end{array}$ & $\begin{array}{l}\text { ca; T; M, CO } \\
\text { Pseudolmedia glabrata (Liebm.) C.C. Berg; }\end{array}$ \\
\hline Persea americana Mill.; aguacate; T; CU; F, & tepetomate; T; WI, CO, F, WI, FU; PU: LF \\
\hline Persea schiedeana Nees; pahua; T; CU; F, M & llo; B; M, F, FR, CO \\
\hline Magnoliaceae & Myrtaceae \\
\hline $\begin{array}{l}\text { Magnolia mexicana DC.; yoloxochitl; T; SP, O, } \\
\text { M, CO; PU; LF, SP }\end{array}$ & $\begin{array}{l}\text { Syzygium jambos (L.) Alston; guayaba rosa; H; } \\
\text { F, FU }\end{array}$ \\
\hline Malpighiaceae & Nyctaginaceae \\
\hline Bunchosia lindeniana A. Juss.; hueso de tigre; & Mirabilis jalapa L.; B; M \\
\hline CO, M; PU: LF, & Pisonia aculeata $\mathrm{L}$ \\
\hline Malvaceae & Passifloraceae \\
\hline Anoda cristata (L.) Schltdl.; H; M, F, FU & Passiflora biflora Lam.; C; O \\
\hline $\begin{array}{l}\text { Hampea integerrima Schltdl.; tecoliste; T; FU, } \\
\text { M; PU: LF }\end{array}$ & $\begin{array}{l}\text { Passiflora filipes Benth.; H; O } \\
\text { Phyllanthaceae }\end{array}$ \\
\hline $\begin{array}{l}\text { Hampea nutricia Fryxell; tecoliste; T; FU, M; } \\
\text { PU: LF }\end{array}$ & $\begin{array}{l}\text { Phyllanthus niruri var. amarus (Schumach. \& } \\
\text { Thonn.) Leandri; manzanillo; H; F }\end{array}$ \\
\hline $\begin{array}{l}\text { Heliocarpus appendiculatus Turcz.; T; M, T, F, } \\
\text { FU, WI, HD, LF }\end{array}$ & $\begin{array}{l}\text { Picramniaceae } \\
\text { Picramnia antidesma Sw.; guayabillo; B; M }\end{array}$ \\
\hline Heliocarpus sp.; jonote; T; F, CO, M & Piperaceae \\
\hline $\begin{array}{l}\text { Malvaviscus arboreus Cav.; marangola; T; M, O } \\
\text { Pavonia schiedeana Steud.; cadillo; H; M }\end{array}$ & $\begin{array}{l}\text { Peperomia macrostachya (Vahl) A. Dietr.; are- } \\
\text { tillo; H; CO, FU }\end{array}$ \\
\hline $\begin{array}{l}\text { Quararibea funebris (La Llave) Vischer; tamo- } \\
\text { lote; T; CO }\end{array}$ & $\begin{array}{l}\text { Peperomia obtusifolia (L.) A. Dietr.; H; O } \\
\text { Peperomia rotundifolia (L.) Kunth; C; O }\end{array}$ \\
\hline Sida acuta Burm. f.; escobilla; H; M & Peperomia sp.; pezma; $\mathrm{H} ; \mathrm{CO}$ \\
\hline Triumfetta sp.; cadillo; A; M & Piper aduncum L.; cordoncillo negro; T; M \\
\hline Melastomataceae & Piper aequale Vahl; cordoncillo; B; M \\
\hline $\begin{array}{l}\text { Conostegia xalapensis (Bonpl.) D. Don ex } \\
\text { DC.; H; F }\end{array}$ & $\begin{array}{l}\text { Piper amalago L.; ashte, cordoncillo blanco; T; } \\
\text { M, R }\end{array}$ \\
\hline $\begin{array}{l}\text { Miconia appendiculata Triana; tezhuilla; } \mathrm{T} \text {; } \\
\text { FU, CO }\end{array}$ & $\begin{array}{l}\text { Piper auritum Kunth; omequelite, acuyo; H; F, } \\
\text { FR, M }\end{array}$ \\
\hline
\end{tabular}


Burgos-Hernández et al.: Potentially useful flora from the tropical rainforest, Veracruz, Mexico

Appendix. Continuation.

Piper dilatatum Rich.; B; M

Piper hispidum Sw.; cordoncillo; H; M

Piper marginatum Jacq.; coapezma; H; CO, M

Piper schiedeanum Steud.; hierba del pazmo; AR; M

Pothomorphe umbellata (L.) Miq.; hierba ceniza; H; R, M

Primulaceae

Ardisia compressa Kunth; B; M, F; PU: O

Ardisia pellucida Oerst.; capulincillo; T; F

Ardisia sp.; capulincillo; B; F

Ranunculaceae

Clematis dioica L.; barba de chivo; C; HD, O, $\mathrm{M}$

Ranunculus petiolaris Kunth ex DC.; H; M

Rhamnaceae

Gouania lupuloides (L.) Urb.; H; M

Rosaceae

Rubus coriifolius Liebm.; zarzamora; B; P

Rubiaceae

Arachnothryx capitellata (Hemsl.) Borhidi; jarilla; T; M

Coffea arabica L.; café; B; CU; F, M, O, FU

Hamelia axillaris Sw.; palo de agua; T; O

Palicourea tetragona (Donn. Sm.) C.M. Taylor \& Lorence; T; PU: O, LF, SP

Psychotria berteriana DC.; palo de agua; B; PU: O

Psychotria costivenia Griseb.; B; O

Psychotria limonensis K. Krause; T; PU: LF, SP

Psychotria sp.; capulin; T; M, F

Sommera arborescens Schltdl.; capulin negro; T; M, F

Spermacoce bahamensis (Britton) R.A. Howard; romerillo; B; WI

\section{Rutaceae}

Citrus maxima (Burm.) Merr.; naranjo cucho; T; CU; F, M, FU, SP
Zanthoxylum riedelianum subsp. kellermanii

(P. Wilson) Reynel; pisijia; B; FU, M, CO

\section{Salicaceae}

Casearia nitida (L.) Jacq.; plomillo; B; FU

Pleuranthodendron lindenii (Turcz.) Sleumer; maicillo; T; WI, FU, CO; PU: LF

\section{Sapindaceae}

Cardiospermum halicacabum L.; C; M

Cupania dentata DC.; guacamayo; T; M, CO, WI, FU; PU: LF, SP

Paullinia clavigera Schltdl.; C; M

Paullinia pinnata L.; chalaguitillo; C; M

Serjania racemosa Schumach.; nueve hojas; H; $\mathrm{M}$

Serjania triquetra Radlk.; H; M

Scrophulariaceae

Buddleja americana L.; palo gusano; T; M, $\mathrm{CO}, \mathrm{FU}$

\section{Siparunaceae}

Siparuna thecaphora (Poepp. \& Endl.) A. DC.; aguacatillo; T; FU, CO

\section{Solanaceae}

Cestrum glanduliferum Kerber ex Francey; huele de noche; $\mathrm{T} ; \mathrm{M}$

Thymelaeaceae

Daphnopsis americana (Mill.) J.R. Johnst.; B; LF

\section{Ulmaceae}

Ulmus mexicana (Liebm.) Planch.; T; T, FU, O, SP

\section{Urticaceae}

Cecropia obtusifolia Bertol.; hormigo; T; M, FU

Urera simplex Wedd.; mal hombre; B; M

Vitaceae

Vitis bourgaeana Planch.; caquiste, parra; C; M, F

Vitis sp.; caquiste, parra; C; M, F 